\title{
Interdependence of Influence between Risk Management Behavior, MSME Characteristics, and Overconfidence on Business Sustainability (A case study in Indonesia)
}

\author{
JALUANTO, Tyoso S. P.*; SUKARDI, Sukardi; DEVITA, Eliza F. \\ Faculty of Economic and Business, University of 17 August 1945 (UNTAG), Semarang, Indonesia. \\ *Corresponding author (bestjalu@gmail.com)
}

PUBLISHED: 21/12/2021

Accepted: 20/12/2021

Submitted: $30 / 11 / 2021$

\section{COPYRIGHT NOTICE:}

\section{CITE THIS PAPER:}

Jaluanto, Tyoso S. P.; Sukardi, Sukardi; Devita, Eliza F. (2021). " Interdependence of Influence between Risk Management Behavior, MSME Characteristics, and Overconfidence on Business Sustainability (A case study in Indonesia)" Journal of World Economy: Transformations \& Transitions (JOWETT) 1(03):09. DOI: https://doi.org/10.52459/jowett1391221

\begin{abstract}
More than 50\% of Micro, Small, and Medium Enterprises (MSMEs) in Indonesia run their business for reasons of livelihood, while 30\% do this since MSMEs are profitable, and may support their living costs. This study aims to determine and analyze the influence of risk management behavior, characteristics of MSMEs through overconfidence on MSME business sustainability, and consequently MSMEs as a source of livelihood. The result of this study indicates that risk management behavior has a significant positive effect on overconfidence, while the characteristics of MSMEs have a significant negative effect on that. In turn, it's shown that overconfidence had a positive and significant effect on the sustainability of MSMEs. However, the characteristics of MSMEs and risk management behavior had no significant positive effect on Sustainable of MSMEs. These results indicate also that MSME entrepreneurs' overconfidence plays a major role in managing their business, which could be considered by the local government and/or the central government in determining MSME policies, such as placements to sell which are given and regulated by each local government considering the accessibility of sellers and buyers as well as their safety.
\end{abstract}

\section{KEYWORDS}

Risk Management Behavior, Overconfidence, MSME Characteristics, Business Sustainability, Indonesia 


\section{INTRODUCTION}

The Ministry of Cooperatives and Small and Medium Enterprises (SMEs) of the Republic of Indonesia reported that in terms of units, Micro, Small and Medium Enterprises (MSMEs) have a share of around 99.99\% (62.9 million units) of the total business actors in Indonesia, while large businesses were only $0.01 \%$ or around 5400 units. Micro enterprises absorbed around 107.2 million workers (89.2\%), small enterprises 5.7 million (4.74\%), and medium enterprises 3.73 million (3.11\%); while big enterprises absorbed around 3.58 million people. This meant that totally, MSMEs absorbed around $97 \%$ of the national workforce, while large businesses only absorb about $3 \%$ of the total national workforce.

Micro, Small, and Medium Enterprises (MSMEs) are jobs that are owned by an individual, or a group of people who work together to create business partnerships to earn income and can benefit each other, which is regulated by Law No. 20 of 2008. MSMEs based on this law have the possibility of growth, which in the future will be a trigger of the rate of economic growth in the whole country, and can become a very large national economic asset. If the process is integrated and focused on development, this potential also acts as a support at the bottom of society. The Ministry of Cooperatives and SMEs run three priority programs to support MSMEs to become national economic assets, namely: providing national-scale MSME empowerment through the entrepreneurial movement, providing various programs to develop cooperatives and MSMEs, and providing easy access to financing for cooperatives and MSMEs.

Table 1

Reasons for MSMEs as Livelihoods

\begin{tabular}{clcc}
\hline No & \multicolumn{1}{c}{ Reason for MSME } & Frequency & Percentage \\
\hline 1 & As a Livelihood & $\mathbf{2 6}$ & $\mathbf{5 2 \%}$ \\
2 & Hobbies & $\mathbf{2}$ & $\mathbf{4 \%}$ \\
3 & New Tried & $\mathbf{3}$ & $\mathbf{6 \%}$ \\
4 & More Profitable & $\mathbf{1 5}$ & $\mathbf{3 0 \%}$ \\
5 & Following the Trend & $\mathbf{4}$ & $\mathbf{8 \%}$ \\
\hline & Quantity & $\mathbf{5 0}$ & $\mathbf{1 0 0 \%}$ \\
\hline
\end{tabular}

Based on the primary data of a survey made by authors, the reasons people seek income through MSMEs are provided in Table 1.

The data in the table above shows that MSMEs are a dream in finding a favorite income or livelihood as people compete to become civil servants. MSMEs must survive and even develop since they are a source of livelihood for those who run them. However, the management of MSMEs requires to pay attention to several related issues, certain variables, such as risk management behavior, MSME characteristics, Overconfidence to lead to attaining MSME entrepreneurs achieving business sustainability. 
Behavior is a series of actions/deeds of an individual or group of people interacting with their environment and themselves, ranging from the most visible behavior to the invisible one, from what was felt to what was not felt (Oktavia \& Trimeiningrum, 2018). Risk management is the application of management function in managing risks, especially those that are faced by organizations/companies, families, and communities. These include activities in planning, organizing, compiling, leading/coordinating, and supervising (including evaluating) risk management programs (Djojosoedarso, 2003). Risk management behavior includes management of risk factors in the workplace/business related to organizational behavior, and industrial psychology of a business to identify, analyze and control risks in each company activity for obtaining higher efficiency (Darmawi, 2014). The focus is on how behavior influences a job or business or organization while reducing the risks and negative impacts of inappropriate behavior.

The financial risk, operating risk, market risk, and strategic risk are considered as main risks in the relevant literature, ( $\underline{\mathrm{COSO}, 2016})$. Research on financial risk has shown that the main type of risk in MSMEs was interest rate risk (Gwangwava, et al., 2014). Risk is an uncertain situation that is expected and causes a loss. Risk is always present in an activity, both company and business. MSMEs need to innovate their products, they can compete with other businesses/businesses, and are able to face various risks that may occur and take advantage of the various opportunities that exist. According to the researchers (Nanthuru, et al., 2018), there was a need for guidance on the risk management process that included risk assessment led to MSMEs for improving their efficiency, and they have the knowledge and understanding of risk management.

This risk management behavior may be the form of MSMEs taking action in dealing with risks and or they created a framework to overcome the risks that would be faced or are being faced. Oktavia and Trimeiningrum (2018), as well as Suryana (2013), suggested that in order to be a successful entrepreneur it's needed to have a clear business idea or vision as well as the willingness and courage to face risks. Serumena, Lena, and Robo (2019) found that risk management affects Sustainable of MSMEs, in the design and implementation of a strategy that could generate relevant information data for the risk management framework of each of their MSMEs logistics areas.

MSMEs are economic or business activities organized by individuals or by a particular organization. Each form of business has its characteristics; one form of business is different from another. Among the MSMEs characteristics may name the number of workers between 1 (one) person to under 20 (twenty) people, the average sales income or turnover per year is IDR 300,000,000 (three hundred million Indonesian Rupiah) to IDR 50,000,000 (fifty billion Indonesian Rupiah), operating profit per year between IDR 18,000,000 - IDR $500,000,000$ (Law No. 20 of 2008 and pre-survey results). The characteristics of MSMEs were believed to be able to affect the sustainability of their business (Widiastuti, 2019). Research by Brustbauer (2014) showed that 
risk management practices were influenced by the characteristics of MSMEs with the ultimate goal of sustainable business.

MSMEs often face the risk of their business being too confident in themselves (overconfidence) to be able to overcome it. Overconfidence and strong determination were said to be able to influence Sustainable MSMEs (Tambunan \& Hasibuan, 2018). The researchers Christanti and Mahastanti (2011) stated that sustainable business affects MSMEs since business actors were too confident in themselves (overconfidence), considering all factors related to business decisions. The longer a business actor runs his business, the fewer or fewer factors are considered, because the longer the experience, the more decisions in business/business are based on experience.

This experience was a cause of overconfidence to have a positive impact on sustainable MSME business (Senjoyo, 2018). A person's overconfidence increases when he gets more business experience (Daniel \& Hirshleifer, 2015), this proves that overconfidence is related to MSME business sustainability. People can be successful in entrepreneurship, in the form of MSMEs, by instilling a strong determination and having high selfconfidence in entrepreneurship (Arifin \& Soleha, 2019). The purpose of this study, therefore, is to determine and analyze the effect of risk management behavior, and the characteristics of MSMEs with overconfidence as an intervening variable on sustainable business.

\section{LITERATURE REVIEW}

Adam, Fernando, and Golubeva (2012) in their research stated that risk management behavior influenced overconfidence. Arifin and Soleha (2019) also stated that there was an influence of risk management behavior on overconfidence and found that overconfidence was influenced by business attitudes in the form of risk management behavior. Their argument suggests that there is an influence between risk management behavior on overconfidence.

The characteristics of MSMEs, including sales turnover, number of employees, profits earned would affect the overconfidence of MSME actors (Oktavia \& Trimeiningrum, 2018), (Suryana, 2013). Serumena, Lena, and Robo (2019) found that MSMEs in designing and implementing a strategy produced relevant data and information, for example, to maintain or increase their sales volume. They prioritize an efficient strategy that will generate profits from any increase in sales volume that is well designed and implemented. Thus, there is an influence between the characteristics of MSMEs on overconfidence.

Overconfidence and strong determination may influence the sustainability of MSMEs (Tambunan \& Hasibuan, 2018), but not everyone can be successful in entrepreneurship. Christanti and Mahastanti (2011) emphasized that business actors who are new to MSMEs, deserve to consider all factors related to business 
decisions, while the longer a business actor runs his business means maintaining or implementing a sustainable business, the fewer factors are considered. The longer the more experience leads to decisions in business are more based on experience. Business experience is the result of fostering a long-term business that can contribute to a very high self-confidence. Regarding this argument, Almilia and Wulanditya (2016) and Senjoyo (2018) mentioned that overconfidence has a significant effect on business decision-making. In the context of this study, SMEs are implementing sustainable MSME business. A person's overconfidence increased when he had more business experiences (Daniel \& Hirshleifer, 2015). The description above provides an understanding that there is an influence between overconfidence on sustainable MSMEs.

\section{RESEARCH METHOD}

The implementation of this study began with conducting a pre-survey to obtain data on MSMEs in the Boja sub-district. The data obtained from the Boja Sub-district were 200 MSMEs in various business fields, including basic food, culinary, services, handicrafts, snacks, clothing, and apparel, building materials and equipment, food ingredients. Samples were taken from these 200 MSMEs as many as 50 by proportionate stratified random sampling to obtain a general picture of the sustainable MSME business. The sample size of this study was 50 MSMEs which were determined based on quota sampling, as respondents. Quota sampling was a technique to determine a sample from a population that has certain characteristics (Ghozali, 2021), which tend to be homogeneous, namely the number of workers 1-20 people, income/turnover per month IDR 2,000,000 - IDR 5,000,000, the length of business is at least 1 (one) year and MSMEs get a profit as a form of permanent attraction for MSMEs to run their business. The sample of this study was 50 MSMEs consisting of 5 basic foods, 12 culinary, 6 services, 2 handicrafts, 18 snacks, 2 clothing and apparel, 1 building materials and equipment, and 4 food ingredients.

Measurement of research variables as follows:

\section{- MSME Characteristics}

MSME characteristics such as the number of workers between 1 (one) person to under 20 (twenty) people, the average sales income or turnover per year are IDR 300,000,000 (three hundred million Indonesian Rupiah) to IDR 50,000,000,000 (fifty billion Indonesian Rupiah), operating profit per year between IDR 18,000,000 - IDR 500,000,000. Variable characteristics of SMEs were measured by the following indicators as Total manpower, Income /Month, Profit/Month, Business Length.

\section{- Risk management behavior}

Risk management behavior itself was defined as how the behavior of MSME actors could survive in their business, minimize/avoid a risk, how to manage risk, and have the principle of being careful in managing risk. Risk management behavior variables were measured by indicators such as risk 
governance and culture, risk, strategy and goal setting, risk in execution, risk information, communication, and reporting, monitoring the company's risk management performance.

\section{- Overconfidence}

Overconfidence was confidence in self-statements that exceed the accuracy of the data provided. This excessive trust made it very easy for entrepreneurs, especially in making decisions in uncertain conditions and limited information, he would step more confidently in making his decisions while the expected success was uncertain, this may essentially be from a sense of optimism as a challenger to a risk. The indicators to measure the overconfidence variable were the personality of self, confidence, risks that arise, trust in big profits, confidence in investment choices, and taking risks.

\section{- Sustainable of Business}

Sustainable of business was the length of the business opening may affect the level of income in MSMEs, the length of time a business person has been in their line of business will affect the productivity of their professional skills to increase efficiency and be able to reduce production costs which are smaller than sales results. This variable was measured by the following indicators as total manpower, income /month, profit/month, business length.

The data has been collected by filling in the questionnaires that were answered by the respondents, then the data was further analyzed using Smart-PLS. The advantages of PLS were its ability to map all paths to many dependent variables in the same research model and analyze all paths in the structural model simultaneously, and in PLS the data did not need to meet the normal multivariate assumption. The reliability test of this research data, as follows.

Tabel 1

Construct Reliability and Validity

\begin{tabular}{lcccc}
\hline \multicolumn{1}{c}{ Variable } & $\begin{array}{c}\text { Cronb } \\
\text { ach's } \\
\text { Alpha }\end{array}$ & rho_A & $\begin{array}{c}\text { Composite } \\
\text { Reliability }\end{array}$ & $\begin{array}{c}\text { Average Variance } \\
\text { Extracted (AVE) }\end{array}$ \\
\hline \hline MSME Characteristics & $\mathbf{0 , 7 9 4}$ & $\mathbf{1 , 0 8 5}$ & $\mathbf{0 , 8 5 3}$ & $\mathbf{0 , 6 6 1}$ \\
Risk management behavior & $\mathbf{0 , 7 1 1}$ & $\mathbf{0 , 7 3 4}$ & $\mathbf{0 , 8 3 8}$ & 0,635 \\
Overconfidence & $\mathbf{0 , 8 4 3}$ & $\mathbf{0 , 8 8 2}$ & $\mathbf{0 , 8 8 8}$ & $\mathbf{0 , 6 1 6}$ \\
Sustainable of Business & $\mathbf{0 , 8 2 3}$ & $\mathbf{0 , 8 3 8}$ & $\mathbf{0 , 8 8 3}$ & $\mathbf{0 , 6 5 6}$ \\
\hline \hline
\end{tabular}

Table 2 made by authors based on primary data processing of the survey, shows that the indicators and variables of this study met the requirements of Cronbach's Alpha was above the value of 0.7 and the AVE value is above 0.5 hence the data of this study may be analyzed further. 


\section{RESEARCH RESULTS AND DISCUSSION}

\section{A. Analysis of Research Results}

In general, respondents gave various responses to the questionnaires submitted. First, the respondent's response to risk management behavior was that they $(62 \%)$ agreed that in running their business facing risk is something they always live. There were three things they have to do, namely dealing with risks, setting strategies, and setting goals for their business to be sustainable. Second, respondents' answers to overconfidence turned out to be $62 \%$, agreeing if they run their business with high confidence. They were too confident which was expressed in "an entrepreneur is my personality" or "this MSME is my life" which was their motivation to survive. $70 \%$ of the respondents answered to the characteristics of MSMEs, where the most dominant characteristic was the monthly sales revenue each because it serves for their daily living expenses and also to purchase other merchandise or services used in their business. Finally, respondents' replied to the sustainability of the business. They responded agreeing (70\%) to survive or maintain their MSMEs as a source of livelihood. They maintained the MSME business by changing their fields of business, such as from the basic food business to changing the business of building materials or livestock or clothing and vice versa.

The next analysis begins with path coefficients, specific indirect effects, R square, f Square.

Table 3

Path Coefficients

\begin{tabular}{lccccc}
\hline \multicolumn{1}{c}{ Variables } & $\begin{array}{c}\text { Original Sample } \\
(\mathbf{O})\end{array}$ & $\begin{array}{c}\text { Sample } \\
\text { Mean } \\
(\mathbf{M})\end{array}$ & $\begin{array}{c}\text { Standard } \\
\text { Deviation } \\
(\text { STDEV })\end{array}$ & $\begin{array}{c}\text { T Statistics } \\
(\mathbf{O} / \text { STDEV) }\end{array}$ & P Values \\
\hline $\begin{array}{l}\text { MSME Characteristics -> } \\
\text { Overconfidence }\end{array}$ & $\mathbf{- 0 , 2 9 0}$ & $-0,283$ & 0,132 & 2,199 & $\mathbf{0 , 0 1 4}$ \\
$\begin{array}{l}\text { MSME Characteristics -> } \\
\begin{array}{l}\text { Sustainable of Business } \\
\text { Overconfidence -> Sustainable of } \\
\text { Business }\end{array}\end{array}$ & $\mathbf{0 , 1 1 5}$ & 0,099 & 0,151 & 0,761 & $\mathbf{0 , 2 2 4}$ \\
$\begin{array}{l}\text { Risk management behavior -> } \\
\text { Overconfidence }\end{array}$ & $\mathbf{0 , 8 1 7}$ & 0,728 & 0,269 & 3,034 & $\mathbf{0 , 0 0 1}$ \\
$\begin{array}{l}\text { Risk management behavior -> } \\
\text { Sustainable of Business }\end{array}$ & $\mathbf{0 , 7 1 4}$ & 0,655 & 0,172 & 4,144 & $\mathbf{0 , 0 0 0}$ \\
\hline
\end{tabular}

In Table 3 made by authors, it's shown that the characteristics of MSMEs have a significant negative effect on Overconfidence. This means that every decrease in value, one of the indicators of characteristics of MSMEs, for example, a decrease in sales in a certain month, will result in a significant decrease in the overconfidence of MSME actors. Then, the characteristics of MSMEs have an insignificant positive effect on sustainable business. This indicates that if there was a change or improvement in the characteristics of MSMEs, it would not necessarily increase business sustainability or increase sustainable business which was not real. 
The increase in sales per month (characteristic of MSMEs), was not a motivation for MSMEs to change business fields in maintaining their MSME business (sustainable business).

On the one hand, Overconfidence has a significant positive effect on sustainable business. This information indicated that increased overconfidence would encourage MSME actors to maintain their business. On the other hand, risk management behavior has a significant positive effect on overconfidence. This situation illustrated that improvements in risk management behavior would increase the overconfidence of MSME actors. In the end, risk management behavior has no significant positive effect on sustainable business. This meant that increasing risk management behavior would not directly encourage MSME actors to increase their sustainable business, for example by adding outlets or selling.

Table 4

Specific Indirect Effects

\begin{tabular}{lcc}
\hline \multicolumn{1}{c}{ Variables } & $\begin{array}{c}\text { Original } \\
\text { Sample (O) }\end{array}$ & P Values \\
\hline MSME Characteristics -> Overconfidence-> Sustainable of Business & $\mathbf{- 0 , 2 3 7}$ & $\mathbf{0 , 0 1 9}$ \\
Risk management behavior $->$ Overconfidence-> Sustainable of Business & $\mathbf{0 , 5 8 3}$ & $\mathbf{0 , 0 0 6}$ \\
\hline
\end{tabular}

Table 4, made by authors, demonstrates that overconfidence was significantly applicable as an intervening variable for the impact of MSME characteristics on the sustainability of business and the effect of risk management behavior on sustainable business. This means that changes in the form of improvements or decreases in the characteristics of MSMEs and risk management behavior would be accompanied by changes in the overconfidence variable which would have a significant impact on changes in the sustainable business variable.

Table 5

R Square

\begin{tabular}{lcc}
\hline \multicolumn{1}{c}{ Variables } & R Square & Adjusted R Square \\
Overconfidence & $\mathbf{0 , 6 3 6}$ & $\mathbf{0 , 6 2 0}$ \\
Sustainable of Business & $\mathbf{0 , 7 1 2}$ & $\mathbf{0 , 6 9 3}$ \\
\hline
\end{tabular}

The $\mathrm{R}$ square results in the Table 5 designed by authors provide that changes in the overconfidence variable were explained by $63.6 \%$ by changes in risk management behavior variables and MSME characteristics, while the rest was explained by other variables not involved in this study. Changes in business variables were due to changes in risk management behavior and characteristics through the change in overconfidence variable of $71.2 \%$, the rest of the changes would be explained by other variables. Adjusted R square shows that there was an opportunity to increase the number of samples between $31 \%-38 \%$ for all variables. This number of samples would increase the accuracy of statistical calculations. 


\begin{tabular}{lcc}
\multicolumn{2}{c}{ Table 6 } \\
& F Square & \\
\hline \multicolumn{1}{c}{ Variables } & Overconfidence & Sustainable of Business \\
\hline MSME Characteristics & 0,229 & $\mathbf{0 , 0 3 7}$ \\
$\begin{array}{l}\text { Overconfidence } \\
\text { Risk management behavior }\end{array}$ & 1,384 & 0,843 \\
\hline
\end{tabular}

The Table 6 shows the value of $f$ squared $>=0.02$ is small; $>=0.15$ moderate; $>=0.35$ large. Values less than 0.02 can be ignored or considered to have no effect between variables. The characteristics of MSMEs have an effect on overconfidence in the medium category. Risk management behavior has the strongest effect on overconfidence, as well as overconfidence has the strongest effect on sustainable business. The results of this study indicate that the variables of risk management behavior and characteristics of MSMEs through the overconfidence variable have a positive and significant effect on the sustainability of a business.

\section{B. Discussion}

\section{The characteristics of MSMEs have a moderate effect on overconfidence}

The result of this study indicated, in Table 6 shows that MSMEs characteristics influenced their overconfidence moderately. The smooth running of the MSME business has been supported by several factors, including the number of workers, sales, and profits (characteristics of MSMEs), their business was able to survive, then analyze competitors, ease of entering new businesses, calculation ability, risk calculation, and overconfidence of MSME actors. The results of this study support the statements of Ligthelm (2010) that business characteristics have an influence on self-confidence, even overconfidence in a positive way. As well as the opinion of Agrawal (2016) who emphasized that the characteristics of MSMEs must be managed properly as a result of their business having a positive effect on the sustainability of MSMEs or sustainable business. In business management, in this case, MSMEs, the overconfidence factor was consciously or unconsciously involved in it. However, it should be considered that the uncertain economic situation affected by Covid-19 has changed all arrangements starting from raw materials, production, and especially the marketing sector which has a huge impact on MSME income, which was also mentioned by Ubaidillah (2020).

\section{Risk management behavior has the strongest influence on overconfidence}

Based on Table 6 it can be concluded that risk management behavior has the strongest influence on the overconfidence of MSMEs actors rather than other variables. This result along with the findings of Adam, Fernando, and Golubeva (2012) confirms that risk management behavior influences overconfidence. Arifin and Soleha (2019) also found the effect of risk management behavior on overconfidence. Also, Douglas and Fitzsimmons (2005) believe that the level of overconfidence was significantly positively related to entrepreneurial intentions to maintain a sustainable business, in this case, MSMEs. Evidence of the interaction 
effect between an individual's entrepreneurial intention and overconfidence ensured his or her business survival behavior. Overconfidence can encourage people to take advantage of opportunities to survive or develop their business (Karunaratne, 2018). Overconfidence was confidence in self-statements that exceed the accuracy of the data provided. This excessive trust greatly facilitates the entrepreneur, especially in making decisions in uncertain conditions and limited information, an entrepreneur would step more confidently in making his decisions while the expected success is uncertain, this can essentially be from a sense of optimism (Belás, 2015).

\section{Overconfidence has a strong effect on sustainable business}

The results of this research provided in Table 6 show that overconfidence has a strong influence on the sustainable business of MSMEs. The result supported the other researchers' findings, including the longer you were in your business, the more you would increase your knowledge of consumer tastes or behavior with the aim of sustainable business (Firdausa \& Arianti, 2013) and has shown that people tend to be optimistic when decisions are made under uncertainty. Uncertainty has two dimensions: market uncertainty and uncertainty about capabilities. A person with overconfidence tends to overestimate their relative abilities (Svenson, 1981). Similar to most people, entrepreneurs hate market risk but, on the other hand, they highly valued their ability (overconfidence) in the context of sustainable business to offset their aversion to risk (Taylor \& Brown, 1988).

Sustainable business in MSMEs could be defined as the concepts and practices undertaken by small, micro, or medium-sized businesses that included businesses that were conducted in a socially responsible manner concerning the way they related to global social, environmental, and local economic issues. Sustainability issues and sustainable business were identified and discussed determining the company's capabilities and assessing the external business environment (Shields \& Shelleman, 2015). Enterprise sustainability is an area that is well practiced in large and small organizations. However, the literature suggests that in the case of MSMEs the situation is different. Social and environmental practices are highly neglected in MSMEs, more specifically in emerging markets. The existing literature mentions that the collaborative modes of operation, government policies, and facilitation, and supportive organizational culture would positively influence the sustainability performance of MSMEs, hence, improve their financial performance (Das, et al., 2020). Furthermore, it should be considered by the local government and/or the central government in determining MSME policies, such as placements or places to sell which are given and regulated by each local government considering the accessibility of sellers and buyers as well as their safety. Other MSME policies may include online promotions organized by the trade and industry offices to encourage the export of MSME products or expand the domestic market.

Micro, Small, and Medium Enterprises (MSMEs) play a key role in the economies of all countries in the world with their contribution to national economic growth and employment. Indonesia for its Middle Income Trap-2045 needs a strong economy to get out of the trap. One way to overcome is to increase economic growth, 
especially the independence of MSMEs (Azzahra \& Wibawa, 2021). However, the relationship between entrepreneurs, risk management behavior, MSMEs, and sustainability (sustainable business) is interdependent (Bernoster, 2018) and success is a sustainability agenda that might be based on risk management behavior, and the characteristics of MSMEs, while MSME growth cannot be achieved without the integration of management behavior risk, MSME characteristics, and overconfidence into their business strategy in order to achieve sustainable business which is supported by the results of this study.

\section{CONCLUSION}

Based on the data analysis provided in this research it can be concluded that risk management behavior has the strongest influence on overconfidence, and the characteristics of MSMEs have a moderate effect on overconfidence, while overconfidence has a strong impact on the sustainability of a business. The results of the study, in brief, confirm that risk management behavior and the characteristics of MSMEs through intervening overconfidence have a strong/significant positive effect on the sustainability of a business. This research also supports the results of previous and current research papers, that MSMEs can be considered as the best alternative for a livelihood during a pandemic and as a national strategy to overcome the middle-income trap.

Regarding the applied research model it should be indicated that the fit of the model was not entirely correct because it uses only 3 (three) independent variables and one dependent variable. Adjusted R square also shows that there is still an opportunity for additional samples, namely $1-0,620=38$ or $38 \%$ because the sample is still small (50 respondents).

Considering the role of MSMEs in the national economies, it is necessary to pay attention to overconfidence and sustainability of businesses as one of the assets of MSMEs. The providing assistance to MSMEs by central and local governments often overlaps, since office "A" provides assistance as well as office "B" and so on. It could be more productive to bring them together into one MSME empowerment movement through the ministry or agency that deals with MSMEs only. Three aspects that must be built and supported to MSMEs as a supportive measure for the national economy are the creation of facilities for a centralized and easily accessible place of business, coordinated with the tourism sector and agents; facilitating the marketing of MSME products; and finally, cooperation with Media, specifically for coverage of MSME product events.

FUNDING: The authors did not receive any external funding.

CONFLICT OF INTEREST: The authors declare no conflicts of interest.

ACKNOWLEDGMENT: Thanks are addressed to the Vice-Chancellor I Untag Semarang, and the Chairperson of Lemlit Untag Semarang who gave wholehearted support in the completion of this research. Likewise, for the Boja Sub-district that facilitated collecting MSME information. 


\section{REFERENCES}

1. Adam, C. S., Fernando, Chitru S. \& Golubeva, E., 2012. Managerial Overconfidence and Corporate Risk Management. Humboldt-Universität zu Berlin Spandauer Straße. DOI:

10.1016/j.jbankfin.2015.07.013 available at: https://ideas.repec.org/a/eee/jbfina/v60y2015icp195208.html

2. Agrawal, R., 2016. Enterprise Risk Management Essential For Survival And Sustainable Development Of Micro Small And Medium Enterprises. International Review. International Review 2016(1-2):117-124 DOI: https://doi.org/10.5937/intrev1602117A

3. Almilia, L. S. \& Wulanditya, P., 2016. The Effect of Overconfidence and Experience on Belief Adjustment Model in Investment Judgement. International Research Journal of Business Studies, 9(1), pp. 39-47. DOI:https://doi.org/10.21632/irjbs.9.1.39-47

4. Arifin, Z. \& Soleha, E., 2019. Overconfidence, Attitude Toward Risk, and Financial Literacy: A Case in Indonesia Stock Exchange. Review of Integrative Business and Economics Research, p. 144-152. Available

at: https://www.researchgate.net/publication/344164472 Overconfidence Attitude Toward Risk and Financial Literacy A Case in Indonesia Stock Exchange

5. Azzahra, B. \& Wibawa, I. G. A. R. P., 2021. Strategi Optimalisasi Standar Kinerja UMKM Sebagai Katalis Perekonomian Indonesia Dalam Menghadapi Middle Income Trap 2045. Inspire Journal: Economics and Development Analysis, pp. 75-86. Available at: https://ejournal.uksw.edu/inspire/article/view/4856

6. Belás, J., 2015. Actual Problems Of Business Risk In SME Segment. Case Study From Slovakia. International Journal of Entrepreneurial Knowledge. https://doi.org/10.37335/ijek.v3i1.26

7. Bernoster, I., 2018. Overconfidence, Optimism, and Entrepreneurship. Journal Sustainability, pp. 1-14. Available at: https://www.researchgate.net/publication/326049561_Overconfidence_Optimism_and_Entrepre neurship

8. Brustbauer, J., 2014. Enterprise risk management in SMEs: Towards a structural model. International Small Business Journal. https://doi.org/10.1177\%2F0266242614542853

9. Christanti , N. \& Mahastanti , L. A., 2011. Faktor-Faktor Yang Dipertimbangkan Investor Dalam Melakukan Investasi. Jurnal Manajemen Teori dan Terapan, pp. 37-

51. http://dx.doi.org/10.20473/jmtt.v4i3.2424

10. COSO, 2016. Enterprise Risk Management—Aligning Risk with Strategy and Performance. s.1.: Available at: https://www.coso.org/documents/COSO-ERM-FAQ.pdf 
11. Darmawi, H., 2014. Manajemen Risiko. Jakarta: Bumi Aksara. Available at: https://pustaka.pu.go.id/biblio/manajemen-risiko/EK821

12. Das, M., Rangarajan, K. \& Dutta, G., 2020. Corporate sustainability in SMEs: an Asian perspective. Journal of Asia Business Studies. http://dx.doi.org/10.1108/JABS-10-2017-0176

13. Daniel, Kent and Hirshleifer, David., 2015. Overconfident Investors, Predictable Returns, and Excessive Trading, Journal of Economic Perspectives, vol.

29/4. http://dx.doi.org/10.1257/jep.29.4.61

14. Djojosoedarso, S., 2003. Prinsip-prinsip Manajemen Risiko dan Asuransi. Jakarta: Salemba Empat. Available at: http://lib.unj.ac.id/buku/index.php?p=show detail\&id=18601\&keywords

15. Douglas, E. \& Fitzsimmons, J., 2005. Entrepreneurial Intentions towards Individual vs. Corporate Entrepreneurship. the SEAANZ 2005 Conference. Available

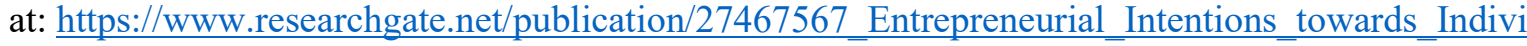
dual_vs_Corporate_Entrepreneurship

16. Firdausa, R. A. \& Arianti, F., 2013. Pengaruh Modal Awal, Lama Usaha Dan Jam Kerja Terhadap Pendapatan Pedagang Kios Di Pasar Bintoro Demak. DIPONEGORO JOURNAL OF ECONOMICS. Available at: https://ejournal3.undip.ac.id/index.php/jme/article/view/1923

17. Ghozali, I., 2021. Structural Equation Modeling, Metode Alternatif dengan Partial Least Square (PLS). Edisi 5. Semarang: Badan Penerbit Universitas Diponegoro.

18. Gwangwava, E. et al., 2014. An Assessment of Risk Management Practices in SMEs in An Assessment of Risk Management Practices in SMEs in Zimbabwe. Journal of Humanities and Social Science. http://dx.doi.org/10.9790/0837-19860614

19. Karunaratne, A. K., 2018. The Impact of Enterprise Risk Management on Firm Performance: Evidence from Sri Lankan Banking and Finance Industry. International Journal of Business and Management. Available at: https://scholar.google.com/citations?

20. Law No.20, 2008. Undang-Undang Republik Indonesia No. 20 Tahun 2008 Tentang Usaha Mikro, Kecil Menengah (UMKM). Jakarta: Available at: https://www.ojk.go.id/sustainablefinance/id/peraturan/undang-undang/Pages/Undang-Undang-Republik-Indonesia-Nomor-20Tahun-2008-Tentang-Usaha-Mikro,-Kecil,-dan-Menengah.aspx

21. Ligthelm, A., 2010. Entrepreneurship and small business sustainability. Southern African Business Review, pp. 131-153. Available

at: https://www.researchgate.net/publication/279341311_Entrepreneurship and small business s ustainability

22. Nanthuru, S. B., Pingfeng, L., Guihua, N. \& Mkonya, V. L., 2018. An Assessment of Risk Management Practices of SME Taxpayers in Malawi and their Impact on Tax Compliance. International Journal of Management Science and Business Administration, pp. 7-

17. http://dx.doi.org/10.18775/ijmsba.1849-5664-5419.2014.44.1001 
23. Oktavia, G. . D. \& Trimeiningrum, E., 2018. Pengaruh Percaya Diri Dan Keberanian Mengambil Risiko Terhadap Keberhasilan Usaha Pada Umkm Makanan Ringan Di Kota Semarang. Jurnal Ekonomi, Manajemen, Akuntansi dan Perpajakan, 1(1), p.

\section{1. https://doi.org/10.24167/jemap.v1i1.1580}

24. Senjoyo, I. K. S., 2018. Pengaruh Karakteristik Wirausahawan Terhadap Kesuksesan UMKM Di Kota Surabaya. AGORA. Available at: http://publication.petra.ac.id/index.php/manajemenbisnis/article/view/7748

25. Serumena, D. R., Lena, P. H. \& Robo, S., 2019. Identifikasi Manajemen Resiko yang diusulkan padaOperasional SME dalam Penerapan Sistem ERP Jangka Panjang. Jurnal RESTI(Rekayasa Sistem dan Teknologi Informasi), pp. 50-58. DOI: https://doi.org/10.29207/resti.v3i1.456

26. Shields, J. \& Shelleman, J. M., 2015. Integrating Sustainability Into SME Strategy. Journal of Small Business Strategy, pp. 59-79. Available at: https://libjournals.mtsu.edu/index.php/jsbs/article/view/561

27. Suryana, 2013. Ekonomi Keatif, Ekonomi Baru: Mengubah Ide dan Menciptakan Peluang. Jakarta: Salemba Empat.

28. Svenson, O., 1981. Are We All Less Risky And More Skillful Than Our Fellow Drivers?. Acta Psychologica, pp. 143-148. http://dx.doi.org/10.1016/0001-6918(81)90005-6

29. Tambunan, F. \& Hasibuan, R., 2018. Pengaruh Percaya Diri Dan Tekad Yang Kuat Terhadap Berwirausaha. Jurnal Administrasi Publik (Public Administration Journal), p.

2. https://doi.org/10.31289/jap.v8i2.1901

30. Taylor, S. E. \& Brown, J. D., 1988. Illusion and Well-Being: A Social Psychological Perspective on Mental Health. Psychological Bulletin, pp. 193-210. Available at: http://faculty.washington.edu/jdb/articles/Illusion\%20and\%20Well-Being.pdf

31. Ubaidillah, M., 2020. Menjaga Keberlangsungan Umkm Pada Masa Wabah Covid-19. INVENTORY: Jurnal Akuntansi, pp. 166-174.

DOI: http://doi.org/10.25273/inventory.v4i2.7674 Available at: http://ejournal.unipma.ac.id/index.php/inventory/article/view/7674/2969

32. Widiastuti , E., 2019. Peningkatan Pengetahuan, Ketrampilan Dan Kemampuan Sumber Daya Manusia Sebagai Strategi Keberlangsungan Usaha Pada Umkm Batik Di Kabupaten Banyumas. Jurnal Ekonomi, Bisnis, dan Akuntansi (JEBA), pp. 1-8. Available at: http://jp.feb.unsoed.ac.id/index.php/jeba/article/view/1286 